\title{
KUALITAS BIODIESEL DARI MINYAK JELANTAH MENGGUNAKAN KATALIS CANGKANG TELUR AYAM RAS DENGAN PERLAKUAN SUHU YANG BERBEDA Zainur Aini', Yahdi', Sulistiyana ${ }^{3}$ 1,2,3Tadris Kimia, FTK UIN Mataram, Mataram, 83116. email: Sulistchemist@uinmataram.ac.id
}

\section{ABSTRAK}

Ketersediaan minyak bumi di Indonesia semakin menipis hal ini menyebabkan terjadinya krisis energi khususnya bahan bakar minyak. Adapun sumber alternatif terbarukan yang dapat dimanfaatkan yaitu biodiesel. Biodiesel merupakan monoalkil ester dari asam lemak rantai panjang yang terkandung dalam minyak nabati atau minyak hewani. Tujuan dalam penelitian ini yaitu untuk mengetahui kualitas biodiesel dari minyak jelantah menggunakan katalis cangkang telur ayam ras dengan perlakuan suhu yang berbeda sesuai dengan SNI biodiesel. Adapun katalis cangkang telur yang digunakan mengandung senyawa $\mathrm{CaCO}_{3}$ sebanyak $94 \%$ dengan proses kalsinasi suhu tinggi. Parameter uji dalam penelitian ini yaitu uji viskositas, uji bilangan asam dan uji kadar air sesuai dengan SNI 7182:2015. Sintesis biodiesel dimulai dengan pembuatan ekstrak katalis $\mathrm{CaO}$ dari cangkang telur ayam ras, kemudian penjernihan minyak jelantah dan pembuatan biodiesel menggunakan metode transesterifikasi dengan variasi suhu reaksi yaitu $55^{\circ} \mathrm{C}, 60^{\circ} \mathrm{C}, 70^{\circ} \mathrm{C}$ dan $80^{\circ} \mathrm{C}$ dengan empat kali pengulangan, kemudian teknik analisa data yang digunakan dalam penelitian ini yaitu pengujian dengan ANOVA (Analisis Of Varian). Hasil yang terbaik untuk uji viskositas dan kadar air terletak pada variasi suhu $80^{\circ} \mathrm{C}$ dengan nilai masing-masing $2.85 \mathrm{~mm}^{2} / \mathrm{s}$ (viskositas) dan $0.02 \%$ (kadar air). Sedangkan pada bilangan asam, nilai terbaik ada pada variasi suhu $70^{\circ} \mathrm{C}$ dengan nilai sebesar $0.275 \mathrm{mg}-\mathrm{KOH} / \mathrm{g}$.

Kata Kunci: Biodiesel, Katalis $\mathrm{CaO}$, Kualitas Biodiesel, Minyak jelantah. 


\section{PENDAHULUAN}

Minyak bumi (Earth Oil) adalah salah satu sumber daya alam yang banyak diaplikasikan sebagai bahan bakar, untuk memenuhi kebutuhan manusia seperti industri, transportasi, dan rumah tangga. Selain itu juga pemakaiannya terus meningkat sesuai dengan pertambahan penduduk dan perkembangan industri yang menyebabkan penyediaan bahan bakar minyak (BBM) meningkat, sehingga ketersediaan minyak bumi ini akan semakin menipis karena minyak bumi tidak dapat diperbaharui (unrenewable) (Mahibin, 2015).

Saat ini cadangan minyak bumi di indonesia semakin sedikit sedangkan jumlah penduduk Indonesia terus meningkat. Bertambahnya jumlah penduduk ini berdampak terhadap meningkatnya berbagai kebutuhan manusia, di antaranya industri dan sarana transportasi. Dampak lainnya adalah meningkatnya kebutuhan dan konsumsi bahan bakar fosil (Mahreni \& Sulistyawati, 2011). Berdasarkan prediksi kebutuhan solar pada tahun 2017 sebesar 3.28 Kiloliter, pada tahun 2018 sebesar 2.77 Kiloliter, sedangkan pada tahun 2019 sebesar 2.33 kiloliter dan pada tahun 2020 sebesar 1.97 Kiloliter. Hal ini membuktikan bahwa penggunaan solar terus terjadi secara signifikan (Raksodewanto, dkk., 2018)

Sementara dari tahun 2004 sampai tahun 2011 cadangan minyak bumi mengalami penurunan dari 8.61 miliyar barel pertahun menjadi 7.73 miliyar barel pertahun. Cadangan energi minyak mentah Indonesia hanya dapat diproduksi atau akan habis dalam kurun waktu 22.99 tahun, gas selama 58.95 tahun dan batubara selama 82.01 tahun. Hasil perhitungan ini menggunakan asumsi bahwa tidak ditemukan lagi ladang-ladang baru sebagai sumber energi fosil. Cadangan energi dapat meningkat (bertahan lama) apabila ditemukan ladang-ladang yang baru atau bahan alternatif yang dapat diperbaharui untuk meningkatkan BBM (Kementerian Energi dan Sumber Daya Mineral, 2009). 
Terjadinya krisis energi, khususnya BBM ini membuat Indonesia perlu mencari sumber-sumber bahan bakar alternatif yang mungkin dikembangkan untuk dapat dimanfaatkan. Jadi untuk mengatasi hal itu pemerintah mengeluarkan Keputusan Presiden No.10 Tahun 2006 tentang Pengembangan Bahan Bakar Nabati (BBN). Indonesia memiliki beragam sumber untuk dimanfaatkan sebagai energi alternatif terbarukan. Salah satu sumber energi alternatif yang terbarukan adalah biodiesel. Biodiesel merupakan monoalkil ester dari asam-asam lemak rantai panjang yang terkandung dalam minyak nabati atau minyak hewani (Mahibin, 2015). Pemanfaatan limbah untuk produksi biodiesel dapat mengurangi dampak lingkungan, menurunkan biaya produksi dan ramah lingkungan. Adapun limbah yang dapat dimanfaatkan pada pembuatan biodiesel ini yaitu minyak goreng bekas.

Berdasarkan definisi bahwa minyak goreng bekas atau yang biasa dikenal dengan minyak jelantah atau minyak goreng bekas (waste cooking oil) ini yaitu limbah minyak yang berasal dari jenis minyak goreng seperti halnya minyak jagung, minyak samin, minyak sayur dan lain sebagainya (Setyawardhani \& Wahyuni, 2009). Adapun minyak ini juga merupakan minyak goreng sisa pemakaian kebutuhan rumah tangga, jika dilihat dari kandungan kimianya, minyak goreng bekas masih mengandung senyawa kimia seperti asam lemak bebas (FFA), peroksida, aldehida, keton, hidrokarbon, alkohol, lakton. Salah satu kandungan FFA dari minyak jelantah menurut Miskah, dkk (2016) menunjukkan hasil uji nilai FFA dari 100\% minyak jelantah yaitu $1.7 \%$. Agar minyak jelantah dapat dimanfaatkan menurut Mahibin (2015) harus diubah melalui proses kimia menjadi biodiesel. Proses pengubahan minyak jelantah menjadi biodiesel adalah melalui reaksi transesterifikasi yaitu mengubah trigliserida dalam minyak dengan metanol dan katalis basa menjadi metil ester.

Berdasarkan proses atau cara pembuatan biodiesel secara kimia ini melalui reaksi yang disebut dengan reaksi transestrifikasi yang dimana menurut definisi bahwa transesterifikasi yaitu reaksi 
antara trigliserida dengan alkohol dapat membentuk biodesel (metil ester) dan sebagai produk samping yaitu gliserol (Hart, dkk., 2003). Kemudian untuk membuat biodiesel, ester dalam minyak nabati perlu dipisahkan dengan gliserol. Ester tersebut merupakan bahan bakar penyusun biodiesel. Selama proses transesterifikasi, komponen gliserol dari minyak nabati digantikan oleh metanol. Metanol adalah alkohol yang dapat dibuat dari batubara, gas alam, atau kayu (Miskah, dkk., 2016).

Penelitian terdahulu yang membahas tentang "Pengaruh waktu adsorpsi minyak jelantah menggunakan arang aktif tongkol jagung sebagai bahan pembuatan biodiesel berkatalis $\mathrm{NaOH}$ terhadap kualitas biodiesel", berdasarkan hasil Kualitas biodiesel yang dihasilkan secara umum telah memenuhi standar SNI. Kualitas tersebut meliputi densitas 0,861-0,868 gr/cm³, viskositas 5,21-5,35 cSt, dan angka asam yang diperoleh yaitu 0,232-0,869 mg KOH/g minyak (Mahibin, 2015). Kemudian hasil penelitian terdahulu tentang pembuatan dan uji kualitas biodiesel dari minyak jelantah atau minyak goreng bekas, menunjukkan bahwa kualitas biodiesel yang dihasilkan yaitu mempunyai mutu yang baik untuk digunakan sebagai bahan bakar karena memenuhi Standar Nasional Indonesia Biodiesel. Kemudian dapat diamati pada nilai hasil uji kualitas yang telah dilakukan dengan membandingkan SNI untuk bahan bakar biodiesel (Syamsidar, 2013). Adapun penelitian terdahulu mengenai pengaruh nanokatalis $\mathrm{ZnO}$ dan $\mathrm{CaO}$ terhadap biodiesel dari minyak biji alpukat, menyatakan bahwa penggunaan katalis alkali pada reaksi transesterifikasi menyebabkan mudahnya terjadi reaksi saponifikasi sehingga membentuk sabun dan katalis alkali ini juga sangat sulit untuk dipisahkan. Oleh sebab itu penggunaan katalis $\mathrm{CaO}$ ini memiliki aktivitas yang tinggi, tahan lama, biaya murah, serta kekuatan basa yang tinggi dan sangat mudah dipisahkan (Lestari, 2018).

Adapun katalis yang dapat digunakan pada reaksi transesterifikasi dari biodiesel ini yaitu katalis padat $\mathrm{CaO}$ yang terkandung di dalam kulit telur ayam ras. Kandungan $\mathrm{CaCO}_{3}$ di dalam kulit telur sekitar $94 \%$ berat, dan sisanya adalah magnesium 
karbonat, kalsium fosfat dan bahan organik. Oleh karena itu dapat diharapkan bahwa kulit telur dapat digunakan sebagai sumber $\mathrm{CaO}$ yang mempunyai kemurnian tinggi sehingga mampu berperan sebagai katalis dalam reaksi transesterifikasi minyak dan metanol menjadi biodiesel. Sumber bahan baku (kulit telur) tersedia cukup banyak dan pada saat ini hanya dibuang (tidak dimanfaatkan), oleh karena itu memanfaatkan kulit telur sebagai katalis merupakan usaha yang cukup relevan untuk mengurangi dampak lingkungan dan menurunkan biaya produksi biodiesel (Miskah, dkk., 2016).

Berdasarkan paparan diatas maka perlu dilakukan penelitian tentang "kualitas biodiesel dari minyak jelantah menggunakan katalis cangkang telur ayam ras dengan perlakuan suhu yang berbeda".

\section{METODE}

\section{ALAT DAN BAHAN}

Alat yang digunakan dalam penelitian ini yaitu gelas beaker $500 \mathrm{ml}$ (Pyrex) dan $250 \mathrm{ml}$ (Pyrex), gelas erlenmeyer $250 \mathrm{ml}$ (IWAKI), $500 \mathrm{ml}$ dan $5000 \mathrm{ml}$ (Pyrex), labu ukur $50 \mathrm{ml}, 100 \mathrm{ml}$ dan $250 \mathrm{ml}$ (Pyrex), saringan halus (Stainless), magnetic stirer, corong pisah $250 \mathrm{ml}$ (Pyrex), kertas saring (Whatman), pemanas listrik (IKA C-MAG HS-7), thermometer (Thermometer Alkohol), oven (memmert), piknometer $25 \mathrm{ml}$ (IWAKI), cawan porselin, stopwatch (Diamond), Ayakan standar ukuran 100 mesh, batang pengaduk (Pyrex), botol kaca, desikator (DURAN), neraca analitik (KERN ABS), kaca arloji, mortal, tungku (muffle furnace), statif, buret basa (Pyrex), pipet tetes, bola hisab dan viskometer Oswald (Pyrex).

Bahan yang digunakan dalam penelitian ini yaitu minyak jelantah, cangkang telur ayam ras, aquadest, metanol, larutan $\mathrm{KOH}$, indikator PP, asam cuka dan air panas.

\section{PROSEDUR}

1. Pembuatan Katalis Cangkang Telur dan Penjernihan Minyak Jelantah

a. Pembuatan Katalis Cangkang Telur 
Ditimbang cangkang telur sebanyak 200 g kemudian dicuci kulit cangkang telur sampai bersih setelah itu dikeringkan pada suhu $105^{\circ} \mathrm{C}$ selama 2 jam selanjutnya ditumbuk dan diperkecil ukurannya menggunakan mortal kemudian diayak dengan menggunakan ayakan 100 mesh setelah itu dikalsinasi pada suhu $900^{\circ} \mathrm{C}$ selama 8 jam sehingga dapat menghasilkan katalis $\mathrm{CaO}$ (Haryono, dkk., 2018).

b. Penjernihan Minyak Jelantah

Diukur minyak jelantah sebanyak $1500 \mathrm{ml}$ kemudian disaring dengan menggunakan kain tipis untuk menghilangkan kotoran dari bekas bahan yang sudah digoreng setelah itu diendapkan minyak yang sudah disaring dari kotorannya, kemudian didiamkan selama 1 hari. Selanjutnya dipisah minyak dengan endapannya. Setelah itu diambil minyak yang sudah dipisahkan dengan endapannya kemudian dicampurkan dengan air pada perbandingan 1:1 dengan dipanasakan pada suhu $100^{\circ} \mathrm{C}$ (Steam) hingga air tersisa setengahnya. Selanjutnya diendapkan selama 30 menit kemudian dipisahkan minyak dari kotorannya sehingga menghasilkan minyak jelantah bersih.

2. Pembuatan Biodiesel

Dipanaskan minyak jelantah bersih yang dihasilkan dengan variasi suhu reaksi yang berbeda yaitu $55^{\circ} \mathrm{C}, 60^{\circ} \mathrm{C}, 70^{\circ} \mathrm{C}$, $80^{\circ} \mathrm{C}$ kemudian dicampurkan dengan larutan $(100 \mathrm{ml}$ metanol dan $5 \mathrm{~g}$ katalis $\mathrm{CaO}$ ) selama 5 jam. Setelah itu dituangkan dalam wadah dengan menggunakan corong pisah dan kemudian diamkan selama sehari. Selanjutnya biodiesel dengan gliserin yang mengendap dipisahkan, setelah itu biodiesel yang telah di pisahkan ditambahkan dengan air yang sudah dicampur dengan $\mathrm{CH}_{3} \mathrm{COOH}$ dengan perbandingan 2:1 (air:cuka) dengan volume 100:50 $\mathrm{ml}$ dan setelah itu diaduk kemudian diamkan campuran selama $1 / 2$ jam sampai 1 jam selanjutnya dipisahkan biodiesel dari 
air kemudian biodiesel yang dihasilkan dipanaskan sampai suhu $110^{\circ} \mathrm{C}$ selama 30 menit sehingga menghasilkan biodiesel murni.

3. Uji Viskositas

Viskositas ditentukan dengan menggunakan alat viskometer Ostwald. Caranya yaitu disiapkan alat viskometer yang digunakan untuk uji cairan yang transparan sesuai dengan sampel yang akan diuji kemudian dibersihkan alat viskometer Oswald dengan aseton atau metanol sehingga bersih dan kering. Setelah itu dimasukkan sampel biodiesel sebanyak $5 \mathrm{ml}$ kedalam viskosimeter kemudian dihisab cairan hingga berada di atas tanda atas viscometer kemudian dibiarkan cairan turun. Selanjutnya dicatat waktu yang diperlukan untuk melewati 2 tanda batas pada viscometer (Nurfadillah, 2011).

4. Uji Bilangan Asam

Dimasukkan sampel sebanyak 20 gr ke dalam Erlenmeyer $250 \mathrm{ml}$ kemudian ditambahkan $50 \mathrm{ml}$ alkohol netral 95\% setelah itu dipanaskan dalam penangas air hingga mendidih sampai terbentuk larutan homogen selanjutnya ditambahkan larutan indikator phenolphthalein 5 tetes didalam alkohol. Kemudian dititrasi dengan $\mathrm{KOH}$ 0,1 $\mathrm{N}$ hingga warna merah jambu yang tidak hilang selama 30 detik. Jumlah volume $(\mathrm{ml}) \mathrm{KOH}$ yang terpakai untuk titrasi kemudian dihitung untuk mengetahui nilai bilangan asam (Adhani, dkk., 2016)

5. Uji Kadar Air

Dipanaskan cawan porselen pada oven dengan suhu $110^{\circ} \mathrm{C}$ selama 15 menit kemudian didinginkan dalam desikator selama 5 menit. Sebanyak $5 \mathrm{~g}$ berat sampel (W1) dimasukkan ke dalam cawan porselen kemudian ditimbang berat cawan + Sampel sebelum dipanaskan (W2). Setelah itu dipanaskan dalam oven dengan suhu $110^{\circ} \mathrm{C}$ selama 4 jam selanjutnya didinginkan dalam desikator selama $1 / 2$ jam (30 menit) kemudian ditimbang berat bawan + sampel setelah dipanaskan (W3). Setelah itu diulang pemanasan dan penimbangan sampai diperoleh bobot tetap/konstan. 


\section{HASIL DAN PEMBAHASAN}

\section{HASIL PENELITIAN}

Adapun hasilnya antara lain:

1. Uji Viskositas

Hasil uji viskositas biodiesel dari minyak jelantah dengan katalis $\mathrm{CaO}$ terhadap berbagai macam variasi suhu reaksi dapat dilihat pada tabel dibawah ini:

Tabel 1. Hasil uji viskositas $\left(\mathrm{mm}^{2} / \mathrm{s}\right)$ biodiesel

\begin{tabular}{cccccc}
\hline Ulangan & Kontrol & $\mathbf{5 5 ^ { \circ } \mathrm { C }}$ & $\mathbf{6 0 ^ { \circ } \mathrm { C }}$ & $\mathbf{7 0 ^ { \circ } \mathrm { C }}$ & $\mathbf{8 0 ^ { \circ } \mathrm { C }}$ \\
\hline 1 & 2.7 & 2.8 & 2.9 & 2.9 & 2.4 \\
2 & 3.5 & 2.8 & 3.2 & 4.0 & 3.5 \\
3 & 4.5 & 3.4 & 2.4 & 3.5 & 29 \\
4 & 5.1 & 2.5 & 3.1 & 3.8 & 2.6 \\
Total & $\mathbf{1 5 . 8}$ & $\mathbf{1 1 . 5}$ & $\mathbf{1 1 . 6}$ & $\mathbf{1 4 . 2}$ & $\mathbf{1 1 . 4}$ \\
Rerata & 3.95 & $\mathbf{2 . 8 7 5}$ & $\mathbf{2 . 9}$ & 3.55 & $\mathbf{2 . 8 5}$ \\
\hline
\end{tabular}

Berdasarkan Tabel 1. tersebut menunjukkan bahwa hasil rerata pengujian viskositas yang memiliki nilai tertinggi yaitu kontrol dengan nilai sebesar $3.95 \mathrm{~mm}^{2} / \mathrm{s}$, selanjutnya dengan suhu $70^{\circ} \mathrm{C}$ dengan nilai $3.55 \mathrm{~mm}^{2} / \mathrm{s}$. Kemudian dilanjutkan suhu $60^{\circ} \mathrm{C}$ dengan skor nilai $2.9 \mathrm{~mm}^{2} / \mathrm{s}$, setelah itu suhu $55^{\circ} \mathrm{C}$ dengan skor $2.875 \mathrm{~mm}^{2} / \mathrm{s}$, dan nilai rerata terendah pada uji viskositas ini berada pada suhu $80^{\circ} \mathrm{C}$ dengan nilai $2.85 \mathrm{~mm}^{2} / \mathrm{s}$. Adapun hasil uji statistik viskositas menunjukkan bahwa $F_{\text {hitung }}<F_{\text {tabel }}(2.687<$ 3.06). Hal ini mengindikasikan bahwa tidak adanya perbedaan yang nyata pada setiap perlakuan.

2. Uji Bilangan Asam

Berikut tabel nilai rerata yang dapat diperoleh dalam pengujian bilangan asam pada kualitas biodiesel sebagai berikut: 
Tabel 2. Hasil uji bilangan asam (mg-KOH/g) biodiesel

\begin{tabular}{cccccc}
\hline Ulangan & Kontrol & $\mathbf{5 5 ^ { \circ } \mathbf { C }}$ & $\mathbf{6 0 ^ { \circ } \mathbf { C }}$ & $\mathbf{7 0 ^ { \circ } \mathbf { C }}$ & $\mathbf{8 0}^{\circ} \mathbf{C}$ \\
\hline 1 & 1.8 & 0.5 & 0.7 & 0.2 & 0.2 \\
2 & 1.1 & 0.7 & 1.1 & 0.4 & 0.3 \\
3 & 1.2 & 0.4 & 1.3 & 0.3 & 0.4 \\
4 & 1.5 & 0.6 & 0.8 & 0.2 & 0.3 \\
Total & $\mathbf{5 . 6}$ & $\mathbf{2 . 2}$ & 3.9 & $\mathbf{1 . 1}$ & $\mathbf{1 . 2}$ \\
Rerata & $\mathbf{1 . 4}$ & $\mathbf{0 . 5 5}$ & $\mathbf{0 . 9 7 5}$ & $\mathbf{0 . 2 7 5}$ & $\mathbf{0 . 3}$ \\
\hline
\end{tabular}

Berdasarkan Tabel 2. mengenai uji bilangan asam (mg$\mathrm{KOH} / \mathrm{g}$ ) pada kualitas biodiesel di atas menunjukkan bahwa nilai rerata tertinggi yaitu kontrol dengan nilai sebesar $1.4 \mathrm{mg}-\mathrm{KOH} / \mathrm{g}$ dan nilai rerata terendah yaitu suhu $70^{\circ} \mathrm{C}$ dengan nilai $0.275 \mathrm{mg}$ $\mathrm{KOH} / \mathrm{g}$. Selanjutnya disusul dengan suhu $80^{\circ} \mathrm{C}$ dengan nilai rerata sebesar $0.3 \mathrm{mg}-\mathrm{KOH} / \mathrm{g}$, kemudian suhu $55^{\circ} \mathrm{C}$ dengan nilai rata-rata $0.55 \mathrm{mg}-\mathrm{KOH} / \mathrm{g}$ setelah itu suhu $60^{\circ} \mathrm{C}$ dengan nilai sebesar $0.975 \mathrm{mg}-\mathrm{KOH} / \mathrm{g}$. Adapun hasil uji statistik bilangan

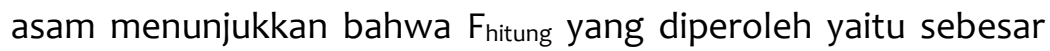
22.290 sedangkan hasil $F_{\text {tabel }}$ sebesar 3.06 pada taraf signifikansi $5 \%$. Maka dinyatakan bahwa $\mathrm{F}_{\text {hitung }}>\mathrm{F}_{\text {tabel }}(22.290>3.06)$. Hal ini mengindikasikan bahwa terdapat perbedaan yang nyata pada masing-masing perlakuan. Oleh karena itu perlu dilanjutkan dengan uji lanjut BNT, adapun dilakukannya uji BNT ini untuk mengetahui perlakuan yang lebih berpengaruh pada bilangan asam biodiesel. Hasil yang didapatkan pada uji BNT sebagai berikut:

Tabel 3. Uji BNT terhadap uji bilangan asam.

\begin{tabular}{lrrc}
\hline Perlakuan & Rata-rata & BNT+Rerata & Notasi \\
\hline $70^{\circ} \mathrm{C}$ & 0.275 & 0.55126744 & $\mathrm{a}$ \\
$80^{\circ} \mathrm{C}$ & 0.3 & 0.57626744 & $\mathrm{a}$ \\
$55^{\circ} \mathrm{C}$ & 0.55 & 0.82626744 & $\mathrm{a}$ \\
$60^{\circ} \mathrm{C}$ & 0.975 & 1.25126744 & $\mathrm{~b}$ \\
KONTROL & 1.4 & 1.67626744 & $\mathrm{C}$ \\
\hline
\end{tabular}


Berdasarkan notasi di atas menunjukkan bahwa nilai rerata pada notasi tidak berbeda signifikan pada tiga perlakuan. Hal ini disebabkan karena nilai rerata perlakuan suhu $70^{\circ} \mathrm{C}, 80^{\circ} \mathrm{C}$ dan $55^{\circ} \mathrm{C}$ memiliki notasi yang sama yaitu "a" sehingga dapat disimpulkan bahwa ketiga perlakuan tersebut tidak berbeda secara signifikan.

3. Uji Kadar Air

Hasil uji kadar air biodiesel dari minyak jelantah dengan katalis $\mathrm{CaO}$ terhadap berbagai macam variasi suhu reaksi dapat dilihat pada tabel dibawah ini.

Tabel 4. Hasil pengujian kadar air (\%-volume) biodiesel

\begin{tabular}{cccccc}
\hline Ulangan & Kontrol & $\begin{array}{c}\text { Suhu } \\
55^{\circ} \mathrm{C}\end{array}$ & $\begin{array}{c}\text { Suhu } \\
60^{\circ} \mathrm{C}\end{array}$ & $\begin{array}{c}\text { Suhu } \\
\mathbf{7 0 ^ { \circ } \mathrm { C }}\end{array}$ & $\begin{array}{c}\text { Suhu } \\
\mathbf{8 0 ^ { \circ } \mathrm { C }}\end{array}$ \\
\hline 1 & 0.03 & 0.02 & 0.02 & 0.02 & 0.02 \\
2 & 0.03 & 0.03 & 0.03 & 0.02 & 0.02 \\
3 & 0.04 & 0.05 & 0.04 & 0.04 & 0.03 \\
4 & 0.03 & 0.03 & 0.02 & 0.04 & 0.01 \\
Total & $\mathbf{0 . 1 3}$ & $\mathbf{0 . 1 3}$ & $\mathbf{0 . 1 1}$ & $\mathbf{0 . 1 2}$ & $\mathbf{0 . 0 8}$ \\
Rerata & $\mathbf{0 . 0 3 2 5}$ & $\mathbf{0 . 0 3 2 5}$ & $\mathbf{0 . 0 2 7 5}$ & $\mathbf{0 . 0 3}$ & $\mathbf{0 . 0 2}$ \\
\hline
\end{tabular}

Berdasarkan Tabel 3. mengenai uji kadar air (\%-volume) pada kualitas biodiesel di atas menunjukkan bahwa nilai rerata tertinggi yaitu kontrol dan suhu $55^{\circ} \mathrm{C}$ dengan nilai $0.0325 \%$, kemudian disusul dengan suhu $70^{\circ} \mathrm{C}$ dengan nilai $0.03 \%$ setelah itu suhu $60{ }^{\circ} \mathrm{C}$ dengan nilai $0.0275 \%$ dan nilai rerata terendah terdapat pada suhu $80{ }^{\circ} \mathrm{C}$ dengan nilai $0.02 \%$. Berdasarkan hasil uji statistik menunjukkan bahwa $\mathrm{F}$ hitung yang diperoleh yaitu sebesar 1.132 sedangkan hasil $F$ tabel sebesar 3.06 pada taraf signifikansi 5\%. Maka dinyatakan bahwa $F_{\text {hitung }}<F_{\text {tabel }}(1.132<$ 3.06). Hal ini mengindikasikan bahwa tidak adanya perbedaan yang nyata pada setiap perlakuan. 


\section{PEMBAHASAN}

1. Uji Viskositas

Uji Viskositas dilakukan untuk mengetahui salah satu karakteristik dari biodiesel yang menunjukkan tingkat kekentalan. Apabila tingkat kekentalan dari produk biodiesel yang dihasilkan sangat tinggi maka akan menyulitkkan aliran, pemompa dan penyala pada mesin. Sebaliknya jika produk biodiesel yang dihasilkan terlalu cair atau encer maka akan menyulitkan bahan bakar untuk terbakar dan akan menyebabkan terjadinya kebocoran didalam pipa injeksi.

Pada penelitian ini pengujian viskositas dilakukan menggunakan alat viskometer Oswald dengan bantuan piknometer untuk mengetahui massa jenis dari produk biodiesel yang akan dianalisa. Hasil yang didapatkan dapat dilihat pada Tabel 1 menunjukkan bahwa hasil rerata pengujian viskositas yang memiliki nilai tertinggi yaitu kontrol dengan nilai sebesar 3.95 $\mathrm{mm}^{2} / \mathrm{s}$, selanjutnya dengan suhu 70 o C dengan nilai $3.55 \mathrm{~mm}^{2} / \mathrm{s}$. Kemudian dilanjutkan suhu $60 \circ \mathrm{C}$ dengan skor nilai $2.9 \mathrm{~mm}^{2} / \mathrm{s}$, setelah itu suhu 55 ㅇ C dengan skor $2.875 \mathrm{~mm}^{2} / \mathrm{s}$, dan nilai rerata terendah pada uji viskositas ini berada pada suhu $80^{\circ} \mathrm{C}$ dengan nilai $2.85 \mathrm{~mm}^{2} / \mathrm{s}$. Adapun nilai rerata yang didapat dalam pengujian viskositas pada setiap variasi suhu, diperoleh hasil yang lebih rendah dan telah sesuai dengan standar umum kualitas biodiesel, menurut SNI 7182:2015 dengan batasan nilai yang ditentukan yaitu $2.3-6.0 \mathrm{~mm}^{2} / \mathrm{s}$. Adapun Proses transesterifikasi biodiesel ini dapat mempengaruhi rendahnya nilai viskositas. Selain itu penambahan katalis $\mathrm{CaO}$ pada reaksi transesterifikasi dengan suhu kalsinasi $900 \circ \mathrm{C}$ dapat mempengaruhi penurunan nilai viskositas minyak jelantah secara optimal dengan mengkonversinya menjadi biodiesel (Yasin, dkk., 2013). Berdasarkan hasil pengamatan bentuk fisik pada kontrol yang terdiri dari minyak jelantah ini lebih kental dibandingkan dengan perlakuan variasi yang lain sehingga minyak jelantah memiliki kekentalan yang lebih tinggi. 
Hasil yang didapatkan peneliti terhadap uji viskositas pada setiap variasi perlakuan telah memenuhi standar nasional Indonesia (SNI 7182:2015) yang secara umum dengan kisaran nilai yang telah ditentukan yaitu sebesar 2.3-6.0 $\mathrm{mm}^{2} / \mathrm{s}$. Kemudian setelah peneliti melakukan analisa uji anova hasil variasi perlakuan tidak berpengaruh secara signifikan karena $F_{\text {hitung }}<\mathrm{F}_{\text {tabel }}$ pada taraf signifikansi $0.05 \%$, sehingga untuk uji lanjut BNT tidak perlu dilakukan.

Hasil yang diperoleh dari penelitian ini untuk setiap variasi perlakuan berkisar $2.85 \mathrm{~mm}^{2} / \mathrm{s}$. Jika dibandingkan dengan uji viskositas yang dihasilkan oleh Nurfadillah yaitu sebesar 5,77 $\mathrm{mm}^{2} / \mathrm{s}$ dan hasil yang didapatkan oleh Mahibin (2015) yaitu 5,34 $\mathrm{mm}^{2} / \mathrm{s}$, dan Qadri (2018) yaitu $5,18 \mathrm{~mm}^{2} / \mathrm{s}$ maka hasil ketiganya lebih tinggi dibandingkan dengan yang dihasilkan dari penelitian ini. Ada berbagai kemungkinan penyebabnya, di antaranya perbedaan katalis, konsentarasi katalis, waktu reaksi dan suhu reaksi yang digunakan pada saat proses transesterifikasi. Proses transesterifikasi dengan bantuan katalis sangat mempengaruhi penurunan nilai viskositas. Semakin tinggi konsentrasi katalis, maka biodiesel yang dihasilkan semakin kental begitupun sebaliknya. Nilai viskositas yang relatif rendah dapat memudahkan aliran dan atomisasi pada mesin. Begitupun sebaliknya jika nilai viskositas terlalu tinggi atau terlalu kental maka akan menyulitkan aliran pada mesin. Jadi viskositas minyak sangat berpengaruh terhadap kesempurnaan bahan bakar dan juga berpengaruh terhadap kerja mesin. Waktu dan suhu reaksi juga berpengaruh terhadap nilai viskositas, semakin tinggi waktu dan suhu yang digunakan dalam proses transesterifikasi maka nilai viskositas semakin rendah. Memang nilai viskositas yang diperoleh pada penelitian ini lebih rendah dari hasil ketiga penelitian terdahulu, namun tetap memenuhi SNI.

2. Uji Bilangan Asam

Bilangan asam merupakan jumlah miligram $\mathrm{KOH}$ yang dibutuhkan untuk menetralkan asam-asam lemak bebas di 
dalam satu gram sampel biodiesel atau bahan baku biodiesel. Pengujian bilangan asam dilakukan melalui proses titrimetri (Oktavia, 2011). Kemudian setelah sampel biodiesel dihasilkan, dilakukan uji bilangan asam dengan proses titrasi asam basa.

Hasil pengujian bilangan asam yang didapatkan pada penelitian ini dapat dilihat pada tabel 2 yang menunjukkan bahwa nilai rerata tertinggi yaitu kontrol dengan nilai sebesar $1,4 \mathrm{mg}-\mathrm{KOH} / \mathrm{g}$ dan nilai rerata terendah yaitu pada variasi suhu $70^{\circ} \mathrm{C}$ dengan nilai sebesar $0,275 \mathrm{mg}-\mathrm{KOH} / \mathrm{g}$ kemudian suhu $80^{\circ} \mathrm{C}$ dengan nilai rerata sebesar $0,3 \mathrm{mg}-\mathrm{KOH} / \mathrm{g}$, selanjutnya suhu $55^{\circ} \mathrm{C}$ dengan nilai rerata $0,55 \mathrm{mg}-\mathrm{KOH} / \mathrm{g}$ dan kemudian suhu $60^{\circ} \mathrm{C}$ dengan nilai sebesar 0,975 $\mathrm{mg}-\mathrm{KOH} / \mathrm{g}$. Dari hasil yang didapatkan semakin rendah nilai bilangan asam maka kualitas biodiesel yang dihasilkan semakin baik begitupun sebaliknya.

Adapun nilai standar bilangan asam menurut SNI 7182:2015 dengan kisaran nilai yang ditentukan yaitu sebesar 0,5 $\mathrm{mg}-\mathrm{KOH} / \mathrm{g}$, sehingga dapat diketahui bahwa rerata terendah yaitu variasi perlakuan pada suhu $70^{\circ} \mathrm{C}$ dan suhu $80^{\circ} \mathrm{C}$, perlakuan ini memiliki nilai rerata lebih kecil dibandingkan standar yang ditentukan sehingga dapat dikatakan memenuhi syarat uji kualitas biodiesel pada bilangan asam. Rendahnya nilai bilangan asam yang dihasilkan disebabkan kandungan asam lemak bebas yang ada pada bahan baku minyak jelantah masih rendah akan tetapi nilai bilangan asam yang tinggi disebabkan kandungan asam lemak pada bahan baku minyak masih tinggi, sehingga minyak jelantah yang memiliki kadar asam lemak rendah ini dapat digunakan sebagai bahan baku dalam pembuatan biodiesel. Pengujian bilangan asam juga dapat digunakan untuk mengetahui sifat korosifitas biodiesel yang dihasilkan. Rendahnya nilai bilangan asam, maka biodiesel yang dihasilkan memiliki kualitas yang baik karena tingkat korosifitasnya juga akan semakin kecil (Kartika \& Yuyun, 2012). Sehingga tidak menyebabkan kerusakan pada mesin.

Adapun hasil bilangan asam pada penelitian ini dengan nilai terkecil pada variasi perlakuan yaitu $0,275 \mathrm{mg}-\mathrm{KOH} / \mathrm{g}$ jika 
dibandingkan dengan hasil yang didapatkan oleh Syamsidar (2013) yaitu dengan nilai sebesar 0,39 mg-KOH/g. Hasil yang didapatkan dalam penelitian ini dengan penelitian yang lain memiliki hasil bilangan asam yang sama-sama sesuai dengan standar yang sudah ditetapkan. Namun, hasil yang didapatkan oleh peneliti lebih kecil dibandingkan peneliti lainnya. Sedangkan hasil yang didapatkan oleh Efendi dkk (2018) pada uji bilangan asam yaitu $0.6818 \mathrm{mg}-\mathrm{KOH} / \mathrm{g}$ terhadap SNI 2006. Nilai yang dihasilkan oleh syahrial ini lebih tinggi dibandingkan dengan hasil yang didapatkan peneliti. Hal ini disebabkan karena kadar asam lemak bebas yang didapatkan oleh masing-masing peneliti berbeda. Adapun kadar asam lemak yang dihasilkan penelitian lain ini sebesar $1.729 \%$ lebih tinggi dibandingkan yang dihasilkan oleh peneliti, dimana hasil yang didapatkan peneliti yaitu $1.024 \%$.

Rendahnya nilai bilangan asam yang dihasilkan disebabkan karena kadar asam lemak bebas pada bahan baku minyak yang digunakan rendah begitupun sebaliknya. Waktu dan suhu yang tinggi pada reaksi transesterifikasi juga dapat menyebabkan penurunan bilangan asam biodiesel.

3. Uji Kadar Air

Uji kadar air adalah tolak ukur kualitas minyak yang digunakan sebagai bahan baku dalam pembuatan biodiesel. Berdasarkan hasil penelitian yang didapatkan dapat dilihat pada tabel 3. Seluruh hasil yang didapatkan peneliti terhadap uji kadar air pada setiap variasi perlakuan ini telah memenuhi Standar Nasional Indonesia (SNI 7182:2015) yang secara umum dengan kisaran nilai yang telah ditentukan yaitu sebesar $0.5 \%$. Adapun nilai rerata pada setiap variasi perlakuan ini masih tergolong rendah dan lebih kecil dibandingkan dengan nilai yang sudah ditetapkan. Oleh karena itu semakin kecil kadar air yang diperoleh maka kualitas semakin baik. Selain itu memperkecil kemungkinan terjadinya reaksi hidrolisis yang dapat menyebabkan kenaikan kadar asam lemak bebas pada 
bahan baku minyak yang digunakan dalam pembuatan biodiesel.

Adapun sebaliknya apabila biodiesel mengandung kadar air yang sangat tinggi maka kualitas yang dihasilkan tidak baik, dapat menyebabkan korosi, menyebabkan turunnya panas pembakaran, berbusa dan bersifat korosif apabila bereaksi dengan sulfur karena akan membentuk asam, kemudian tingginya kadar air ini juga dapat menyebabkan kerusakan pada mesin dan tumbuhnya mikro organisme yang menyumbat aliran bahan bakar.

Hasil uji kadar air yang diperoleh dari penelitian ini adalah $0.02 \%$. Hasil ini sama dengan yang diperoleh Musta dkk (2017) yaitu $0.02 \%$, namun lebih tinggi dibandingkan yang diperoleh Nurfadillah (2011) yaitu 0.01\%, dan lebih rendah dibandingkan hasil yang diperoleh Efendi dkk. (2018) yaitu 0.044\%.

Rendahnya kadar air biodiesel yang dihasilkan maka reaksi hidrolisis tidak terjadi dan kandungan asam lemak semakin kecil. Kemudian rendahnya kadar air yang dihasilkan juga disebabkan karena waktu dan suhu yang digunakan dalam proses reaksi cukup tinggi atau cukup lama, kemudian tingginya waktu dan suhu yang digunakan ini menyebabkan air menguap secara sempurna, sehingga kadar air yang terdapat dalam biodiesel rendah. Begitupun sebaliknya apabila kandungan air terlalu tinggi dalam biodiesel maka dapat menyebabkan turunnya panas pembakar, berbusa, bersifat korosif dan memberi ruang bagi mikroba untuk tumbuh sehingga akan menjadi pengotor bagi biodiesel.

\section{KESIMPULAN}

Berdasarkan hasil pengamatan, analisa data dan pembahasan maka disimpulkan bahwa Kualitas biodiesel yang berbahan baku minyak jelantah dan katalis cangkang telur ayam ras dengan perlakuan suhu berbeda hanya berbeda nyata pada uji bilangan asam, sedangkan untuk uji viskositas dan kadar air tidak berpengaruh secara signifikansi. Kualitas Biodiesel yang dihasilkan 
sesuai dengan SNI biodiesel yang telah ditetapkan. Uji viskositas yaitu berkisaran 2.3-6.0 mm²/s. Begitupun dengan uji kadar air menunjukkan bahwa kualitas biodiesel yang dihasilkan sesuai dengan standar umumnya yaitu $0.05 \%$. Hasil uji bilangan asam memenuhi standar umum yait u variasi perlakuan pada konsentrasi suhu $70^{\circ} \mathrm{C}$ dan $80^{\circ} \mathrm{C}$ dengan nilai suhu $70^{\circ} \mathrm{C}$ yaitu 0.275 $\mathrm{mg}-\mathrm{KOH} / \mathrm{g}$ dan suhu $80^{\circ} \mathrm{C}$ dengan nilai $0.3 \mathrm{mg}-\mathrm{KOH} / \mathrm{g}$ adapun nilai standar yang sudah ditentukan untuk uji bilangan asam yaitu berkisaran $0.5 \mathrm{mg}-\mathrm{KOH} / \mathrm{g}$.

\section{DAFTAR PUSTAKA}

Adhani L., Aziz, I., Nurbayti, S. \& Oktaviana, C. O. (2016). Pembutan Biodiesel dengan Cara Adsorpsi dan Transesterifikasi dari Minyak Goreng Bekas. Jurnal Kimia VALENSI: Jurnal Penelitian dan Pengembangan Ilmu Kimia. 2(1). Mei 2016, hlm. 73.

Efendi, S., Hamzah, F. H \& Ali, A. (2018). Konsentrasi Katalis CaO dari Cangkang Telur Ayam pada Proses Transesterifikasi Biodiesel Minyak Biji Pangi. Jurnal JOM FAPERTA. 5 (1). 1-12.

Hart, H, Craine, L. E. \& Hart D. J. (2003). Kimia Organik. Erlangga: Jakarta.

Haryono., Natanael, C. L., Rukiah., \& Yulianti, Y. B. (2018). Kalsium Oksida Mikropartikel dari Cangkang Telur Sebagai Katalis pada Sintesis Biodiesel dari Minyak Goreng Bekas. Jurnal Material dan Energi Indonesia, Vol.08, (01). 8-15.

Kartika, I. A. \& Yuyun, P. (2012). Optimasi Produksi Biodiesel dari Biji Jarak Pagar melalui Transestrifikasi In Situ Menggunakan Metode Respon Permukaan. E-Jurnal Agroindustri Indonesia. 1(2). 68-74.

Kementerian Energi dan Sumberdaya Mineral. (2009). Handbook of Energy and Economic Statistic of Indonesia. Center for Data and Information on Energy and Mineral Resources. Ministry Energy and Mineral Resources: Jakarta. hlm. 23. 
Lestari, P. P. (2018). Pengaruh Nanokatalis ZnO/CaO Terhadap Biodiesel dari Minyak Biji Alpukat. Jurnal Kimia Saintek Dan Pendidikan. 2 (1). 1-8.

Mahibin. (2015). Pengaruh Waktu Adsorpsi Minyak Jelantah Menggunakan Arang Aktif Tongkol Jagung Sebagai Bahan Pembuatan Biodiesel Berkatalis $\mathrm{NaOH}$ Terhadap Kualitas Biodiesel. IKIP Mataram, Mataram. hlm. 8-9.

Mahreni \& Sulistyawati, E. (2011, Juli). Pemanfaatan Kulit Telur Sebagai Katalis Biodiesel Dari Minyak Sawit Dan Metanol. Seminar Rekayasa Kimia dan Proses. Yogyakarta. 1-6.

Miskah, S., Anugrah, A., \& Gunadi. (2016). Pemanfaatan Kulit Telur Sebagai Katalis Biodiesel dari Campuran Minyak Jelantah dan Minyak Kelapa Sawit. Jurnal Teknik Kimia. 22 (2). 54-61.

Musta, R., Haetami A.\& Salmawati, M. (2017). Biodiesel of The Transesteriation Product Calophyllum Inophyllum Seed Oil from Kendari Using Methanol Solution. Indonesian Journal of Chemical Research. 4(2). 394-401.

Nurfadillah. (2011). Pemanfaatan dan Uji Kualitas Biodiesel dari Minyak Jelantah. Fakultas Sains dan Teknologi Universitas Islam Negeri (UIN) Alauddin Makassar: Makassar.

Oktavia, R. Z. (2011). Pembuatan dan Uji Kualitas Bahan Bakar Alternatif (Biodiesel) dari Minyak Kelapa (Cocos nucifera). Universitas Islam Negeri (UIN) Alauddin Makassar: Makassar. Qadri, M.F. (2018). Pengaruh Variasi Mol Metanol Dengan Minyak Goreng Bekas Dan Konsentrasi K Pada Proses Impregnasi Terhadap Katalis $\mathrm{CaO}$ dalam Pembuatan Biodiesel. Politeknik Negeri Samarinda, Samarinda.

Raksodewanto, A. A., Abrori, M. \& Hariana. (2018, Oktober). Penggunaan Biodiesel B30 untuk Sektor Pembangkit Listrik dalam Rangka Penghematan Devisa. Seminar Nasional Sains dan Teknologi. Fakultas Teknik Universitas Muhammadiyah Jakarta: Jakarta.

Setyawardhani, D. A. \& Wahyuni, M. (2009). Pengaruh Rasio Metanol atau Minyak Terhadap Parameter Kecepatan Reaksi 
Metanolisis Minyak Jelantah dan Angka Setana Biodiesel. Teknik Kimia Fakultas Teknik UNS. diakses Tgl 26 januari 2020. Syamsidar, H. S. (2013). Pembuatan dan Uji Kualitas Biodiesel dari Minyak Jelantah. Jurnal Teknosains. 7 (2). 209-218.

Yasin, M. H. M., Mamat, R., Yusop, A. F., Rahim, R., Aziz, A., \& Shah, L. A. (2013). Fuel Physical Characteristics of Biodiesel Blend Fuels with Alcohol as Additives. Procedia Engineering.53.701706. 